NBER WORKING PAPER SERIES

HEALTHY LIVING IN HARD TIMES

Christopher J. Ruhm

Working Paper 9468

http://www.nber.org/papers/w9468

\author{
NATIONAL BUREAU OF ECONOMIC RESEARCH \\ 1050 Massachusetts Avenue \\ Cambridge, MA 02138 \\ January 2003
}

I thank Peter Bearse, Ken Snowden and seminar participants at IZA, North Carolina State, Rand, Stanford, and the University of California at Santa Cruz for helpful comments; Olga Khavjou provided superb research assistance. Financial support for this research was provided by the National Science Foundation (SES-9876511). The opinions, findings, and conclusions are those of the author and do not necessarily reflect the views of the funding agency or the National Bureau of Economic Research.

(C2003 by Christopher J. Ruhm. All rights reserved. Short sections of text not to exceed two paragraphs, may be quoted without explicit permission provided that full credit including notice, is given to the source. 
Healthy Living in Hard Times

Christopher J. Ruhm

NBER Working Paper No. 9468

January 2003

JEL No. E32, I12, J20

\begin{abstract}
Using microdata for adults from the 1987-2000 years of the Behavioral Risk Factor Surveillance System, I show that smoking and height-adjusted weight decline during temporary economic downturns while leisure-time physical activity rises. The drop in tobacco use occurs disproportionately among heavy smokers, the fall in body weight among the severely obese, and the increase in exercise among those who were completely inactive. Declining work hours may provide one reason why behaviors become healthier when the economy weakens, possibly by increasing the non-market time available for lifestyle investments. Conversely, there is little evidence that reductions in income play an important role. The overall conclusion is that changes in behaviors supply one mechanism for the procyclical variation in mortality and morbidity observed in recent research.
\end{abstract}

Christopher J. Ruhm

Department of Economics

University of North Carolina at Greensboro

P.O. Box 26165

Greensboro, NC 27402-6165

and NBER

c_ruhm@uncg.edu 


\section{Healthy Living in Hard Times}

Recent evidence indicates that mortality decreases when the economy temporarily deteriorates. Using aggregate data for a panel of the 50 states and District of Columbia over a 20-year period (1972-1991), Ruhm (2000) estimates that a one percentage point rise in unemployment reduces the total death rate by 0.5 percent. Compared to earlier research, this analysis has the advantage of using fixed-effect (FE) models that exploit within-state changes and so automatically control for time-invariant factors that are spuriously correlated with economic conditions across locations. ${ }^{1}$ Using similar methods, other studies document a fall in total fatalities during downturns utilizing aggregate data for 50 Spanish provinces over the 19801997 period (Tapia Granados, 2002), 16 German states from 1980-2000 (Neumayer, 2002), and 23 OECD countries between 1960 and 1997 (Gerdtham and Ruhm, 2002). ${ }^{2}$

Although reductions in external sources of death (such as accidents) account for a small portion of the lower mortality, most of the decrease reflects better health. ${ }^{3}$ According to Ruhm (2000), the one point rise in unemployment lowers fatalities from cardiovascular disease, influenza or pneumonia, and liver ailments by $0.4,0.7$, and 0.4 percent. ${ }^{4}$ Moreover, the health

\footnotetext{
${ }^{1}$ Widely cited analyses of aggregate time-series data by Harvey Brenner (1973, 1975, and 1979) reveal a countercyclical variation in admissions to mental hospitals, infant mortality rates, and deaths due to cardiovascular disease, cirrhosis, suicide, and homicide. However, this research suffers from serious technical flaws (Gravelle, et al., 1981; Stern, 1983; Wagstaff, 1985; Cook \& Zarkin, 1986) and studies correcting the problems (Forbes \& McGregor, 1984; McAvinchey, 1988; Joyce \& Mocan, 1993) fail to uncover a consistent relationship between the macroeconomy and health. Instead, the results are sensitive to the choice of countries, time periods, and outcomes, with falling unemployment frequently being correlated with worse rather than better health. The lack of robustness is unsurprising since any lengthy time-series may contain factors that are confounded with economic conditions. For instance, dramatic reductions in joblessness at the end of the great depression were accompanied by spuriously correlated improvements in health due to better nutrition and increased availability of antibiotics.

${ }^{2} \mathrm{~A}$ one percentage point decrease in unemployment is estimated to raise total mortality by between 0.3 and 1.1 percent in these studies.

${ }^{3}$ The aforementioned analyses all document a strong procyclical variation in traffic fatalities, which occurs at least partly because driving decreases when the economy worsens. Ruhm (2000) estimates that external sources account for 22 to 26 percent of the cyclical fluctuation in total mortality.

${ }^{4}$ Gerdtham and Ruhm (2002) uncover reductions in mortality from cardiovascular disease, influenza/pneumonia, and liver ailments during bad economic times. Neumayer (2002) obtains similar results for the first two of these sources but not for deaths from liver disease.
} 
improvements are not limited to reductions in deaths. In microdata from the 1972-1981 years of the National Health Interview Survey and controlling for personal characteristics, fixed-effects, general time effects, and state-specific trends, a one percentage point rise in unemployment predicts a 1.5 percent fall in the prevalence of medical problems, a 3.9 percent decline in acute morbidities, and a 1.6 percent reduction in reports of "bed-days" during the prior two weeks; some chronic conditions also become less common, led by a 4.3 percent decrease in ischemic heart disease and an 8.7 percent reduction in intervertebral disk disorders (Ruhm, 2002).

This paper provides evidence that one reason for gains in physical health during macroeconomic downturns is because of changes in lifestyles. Data for adults from the 19872000 years of the Behavioral Risk Factor Surveillance System (BRFSS) indicates that smoking, height-adjusted weight, and leisure-time physical inactivity decline when economic conditions worsen. The drop in tobacco use disproportionately occurs among heavy smokers, the fall in body weight among the severely obese, and the increase in exercise among those who were completely inactive. Since each of these are major risk factors, the behavioral changes supply an important mechanism for the countercyclical variation in physical health. ${ }^{5}$

There are at least two reasons why individuals might adopt healthier lifestyles when the economy weakens. First, increases in non-market time make it less costly to undertake healthproducing activities such as exercise or the consumption of a healthy diet. Second, reductions in incomes and employment-related stress could decrease the use of "self-medication" through

\footnotetext{
${ }^{5}$ It is noteworthy that aforementioned research documents larger fluctuations in morbidity and mortality from sources such as cardiovascular disease, that are likely to be strongly affected by short-term changes in lifestyles, than for those such as cancer that probably are not. Behavioral changes are not the only reason why physical health might worsen when the economy strengthens. For instance, health may be an input into the production of goods and services. Thus, hazardous working conditions, the exertion of employment, and job-related stress could have negative effects, particularly when job hours are extended during short-lasting economic expansions (Baker, 1985; Karasek and Theorell, 1990; Sokejima and Kagamimori, 1998). Employment is considered a health risk in the environmental medicine literature (e.g. see Harber et al., 2001) and some joint products of economic activity, such as pollution, adversely affect health (e.g. see Chay and Greenstone, 2001).
} 
smoking and drinking. ${ }^{6}$ The analysis below suggests that only the first of these is important. Specifically, while there is no indication that the behavioral changes reflect declining incomes, decreases in employment hours are associated with reductions in health risks.

Three additional points deserve mention. First, although physical health improves during downturns, mental health may deteriorate. ${ }^{7}$ Thus, previous research hypothesizing a role for increasing stress when the economy deteriorates (e.g. Brenner and Mooney, 1983; Catalano and Dooley, 1983; Fenwick and Tausig, 1994) may be correct, even while mistaking this to imply a more general decline in health. Second, healthier lifestyles need not be restricted to or concentrated among those becoming newly unemployed. Instead, the stress of job loss could induce negative effects that contrast with benefits for workers whose hours or job-related pressures are reduced. Third, worse health during temporary expansions does not imply negative effects of permanent economic growth. The key distinction is that agents have greater flexibility in making consumption, time-allocation, and production decisions in the long-run. Transitory increases in output usually require more intensive use of labor and health inputs with existing technologies. Conversely, long-term growth results from technological improvements or expansions in the capital stock that pushes out the production possibility frontier, potentially ameliorating costs to health. Individuals are also more likely to defer health investments in

\footnotetext{
${ }^{6}$ Previous research provides some support for these possibilities. Several studies show that alcohol use falls in bad times, with particularly large reductions in heavy drinking (Ruhm, 1995; Freeman, 1999; Ruhm and Black, 2002). Ruhm (2000) presents preliminary evidence that smoking and body weight also decline while physical activity increases and diets improve. Chou, Grossman, and Saffer (2002) indicate that obesity is negatively related to the time price of obtaining (calorie-rich) prepared food and positively correlated with that of cooking (lower-calorie) meals at home (with time prices proxied by work hours and the per capita number of restaurants). The time price of medical care may also decrease in bad times if persons employed fewer hours find it easier to schedule medical appointments. Consistent with this, Mwabu (1988) and Vistnes and Hamilton (1995) report a negative relationship between employment and the utilization of medical care. However, Ruhm $(2000,2002)$ presents evidence of a procyclical variation in the use of health services.

${ }^{7}$ For instance, both suicides and non-psychotic mental disorders are countercyclical (Ruhm, 2000, 2002).
} 
response to temporary than lasting increases in work hours and sustained growth permits purchases of consumption goods (like safer cars) that improve health. ${ }^{8}$

\section{Data and Methods}

Data are from the 1987-2000 interview years of the Behavioral Risk Factor Surveillance System, an annual telephone survey of the non-institutionalized adult population administered by the Centers for Disease Control and Prevention. Thirty-four states participated in 1987 and at least 45 throughout the 1990s. Sample sizes are large, exceeding 50,000 in each year analyzed, and increase over time so that the 14-year sample contains almost 1.5 million observations. ${ }^{9}$

The BRFSS consists of core questions, asked by all states in the specified year, and optional modules included by some states but not others. Most information is comparable over time and across locations. The survey is particularly useful because it is designed to produce uniform state-specific data measuring progress towards meeting the Healthy People 2010 national health promotion and disease prevention objectives and so considers a variety of healthrelated behaviors. ${ }^{10}$ Specifically, questions on smoking, height, and weight are in the core survey in every year, as is information on leisure-time physical activity for all years except 1993, 1995, 1997, and 1999 (where it is in optional modules included by 9, 11, 12, and 11 states). ${ }^{11}$ Demographic data on age, sex, education, marital status, and race/ethnicity are also available for all years and respondents.

\footnotetext{
${ }^{8}$ See Ettner (1996) or Pritchett and Summers (1996) for evidence of a positive relationship between permanent income and health. Graham, Chang, and Evan's [1992] analysis of U.S. time-series data indicates that mortality rates are negatively (positively) related to permanent (transitory) income. However, Snyder and Evans (2002) find that reduced incomes of the Social Security "notch" beneficiaries are associated with decreased mortality.

${ }^{9}$ Persons without phones or in non-residential settings (e.g. military bases, college dorms, or institutions) are excluded. Also, no information is provided on youths (under the age of 18) and the data are self-reported.

${ }^{10}$ Additional information on Healthy People 2010 can be obtained from: http://www.health.gov/healthypeople. Further details on the BRFSS are available at: http://www.cdc.gov/nccdphp/brfss.

${ }^{11}$ Exercise data are available for 16,141, 23,677, 28,767, and 28,457 individuals in 1993, 1995, 1997, and 1999.
} 


\subsection{Outcomes}

Smoking, the most important preventable cause of disease in the United States, leads to an estimated 430,000 premature deaths annually due to increased risk of cancer, coronary heart disease, stroke, respiratory illness, and many other ailments (Report of the U.S. Preventive Services Taskforce, 1996; U.S. Department of Health and Human Services, 2000). Since tobacco use varies with prices and incomes, reductions in consumption might help to explain why health improves when the economy weakens. ${ }^{12}$ Respondents are classified below as "current smokers" if they smoke every day or some days (rather than not at all), with two other dichotomous variables indicating tobacco use of at least 20 or 40 cigarettes daily. ${ }^{13}$

Obesity is the second leading cause of preventable death and a major risk factor for hypertension, type- 2 diabetes, coronary heart disease, stroke, gallbladder disease, respiratory problems and several types of cancer (National Heart, Lung, and Blood Institute, 1998). Three hundred thousand deaths are attributed to excess weight annually and its estimated economic cost was $\$ 117$ billion in 2000 (U.S. Department of Health and Human Services, 2001). Binary variables classify persons as "overweight", "obese", and "severely obese" if their body mass index (BMI) is at least 25,30 , or $35 .{ }^{14}$ These definitions, recommended by the National

\footnotetext{
${ }^{12}$ Chaloupka and Warner (2000) provide a comprehensive overview of economic issues related to smoking.

${ }^{13}$ Prior to 1996, the BRFSS contained a single question on the number of cigarettes smoked per day. Beginning in 1996, this information was obtained for daily smokers only, with others asked the average amount smoked on days of tobacco use. Therefore, in these later years, the 20 and 40 cigarette dummy variables were set to one for daily smokers reporting smoking at least this much. Warner (1978) presents evidence that smoking is substantially understated in self-reported data such as the BRFSS. The main conclusions below will be unaffected, however, if the underreporting is independent of economic conditions.

${ }^{14}$ BMI, defined as weight in kilograms divided by height in meters squared, is a favored method of assessing excess weight because it is simple, rapid, and inexpensive to calculate. The cutoffs for being overweight, obese, and severely obese are 155, 186, or $217(184,221$, and 258) pounds for a person who is 5 feet 6 inches (6 feet) tall. There is error in self-reported data, most importantly because heavier persons (especially women) tend to understate their weight. I employ a variation of the procedure used by Cawley (2000) to correct for this. The method involves: 1) regressing actual weight (height) on a quadratic of self-reported weight (height) using data from physical examinations and self-reports in the third National Health and Nutrition Examination Survey (NHANES III); 2) taking the coefficients from these regressions to adjust self-reported height and weight in the BRFSS data; and 3) calculating BMI using the adjusted values for weight and height. I allow for different reporting errors across
} 
Institutes of Health (National Heart, Lung, and Blood Institute, 1998), have become standard in recent obesity research (e.g. Mokdad, et al., 1999; Chou, Grossman, and Saffer, 2002). ${ }^{15}$

Regular physical activity is associated with lower risk of heart disease, diabetes, colon cancer and osteoporosis; exercise also increases muscle and bone mass, is a key component of weight loss efforts, and enhances psychological well-being (U.S. Department of Health and Human Services, 1996, 2000). Using an index included in the BRFSS, dichotomous variables are created indicating persons who were "physically inactive" or engaged in no more than “irregular" exercise. The reference group of "regular" exercisers participated in an activity or pair of physical activities for at least 20 minutes three or more times per week. Individuals were "inactive" if they did not take part in any physical activity outside of the regular job duties during the month preceding the survey. "Irregular" exercise is the intermediate category. ${ }^{16}$

Finally, a dichotomous variable indicates "multiple" health risks, for persons with two or more of the conditions of current smoking, severe obesity, or physical inactivity.

\section{$\underline{1.2 \text { Explanatory Variables }}$}

The main proxy for economic conditions is the average state unemployment rate, over the preceding three months for the civilian non-institutionalized population (aged 16 and over). Data are from the Bureau of Labor Statistics Local Area Unemployment Statistics (LAUS) Database. ${ }^{17}$ Some models also control for annual household income (in thousands of 2000 year dollars) or weekly work hours. The former is calculated as a weighted average for BRFSS

\footnotetext{
demographic groups by estimating the equations separately for males and females and including interactions between race (black vs. nonblack) or Hispanic origin and self-reported height or weight.

${ }^{15}$ The severely obese category includes persons with class II (BMI between 35 and 40) and class III (BMI above 40) obesity. This grouping has previously been used by Allison et al. (1999). Although low BMI (less than 18.5) may also represent a health risk, fewer that 2 percent of respondents are "underweight" by this standard and the estimated effect of economic conditions on low weight is always small and statistically insignificant.

${ }^{16}$ The BRFSS also includes a measure of "vigorous" exercise but its definition changed in 1992.

${ }^{17}$ The web-site http://stats.bls.gov/lau/home.htm contains information on the LAUS.
} 
residents in the state with the same sex, age, and education as the respondent. ${ }^{18}$ Current Population Survey Outgoing Rotation Group (CPS-ORG) data are used to estimate a three-month trailing average of the latter for adults in the respondent's state-sex-age-education cell. ${ }^{19}$

I use group averages rather than individual values for the last two variables because the respondent's income and work hours will be simultaneously determined with health status. For instance, a negative association between income and body weight could occur because obesity reduces earnings (Cawley, 2000) or due to unobserved confounding factors, rather than because incomes cause weight. Estimates that primarily exploit cross-sectional variations are therefore likely to suffer from omitted variable and endogeneity bias. Those utilizing group-level variations are unlikely to have these problems but will be less precisely estimated.

The econometric models also include a quadratic in years of age and dummy variables for sex, education (high school dropout, some college, college graduate), race/ethnicity (nonHispanic black, other non-Hispanic nonwhite, Hispanic origin), and marital status (married, divorced/separated, widowed). Information on education or marital status is missing for 0.4 percent of respondents (5660 persons). To avoid excluding these individuals, the relevant regressors were set to zero and missing value dummy variables created. ${ }^{20}$

\subsection{Descriptive Information}

The first column of Table 1 displays unweighted sample means; the second column incorporates BRFSS sampling weights. Weighting has little effect on the prevalence of smoking,

\footnotetext{
18 The BRFSS reports household income in the ranges: less than $\$ 10,000, \$ 10,000-\$ 14,999, \$ 15,000-\$ 19,999$, $\$ 20,000-\$ 24,999, \$ 25,000-\$ 34,999, \$ 35,000-\$ 49,999$, and $\$ 50,000$ or above $(\$ 50,000-\$ 74,999$ and 75,000 or above after 1995). For the econometric estimates, individual household incomes are assumed to be at the midpoint of each range and 150 percent of the (unbounded) top category, converted to 2000 year dollars using the all-items CPI. Average incomes are calculated for 16 groups stratified by sex (male vs. female), age (18-24, 25-54, 55-64, 65 and over), and education (no college vs. some college).

${ }^{19}$ Data are from the National Bureau of Economic Research "Current Population Survey Merged Outgoing Rotation Groups: 1979-2000” CD-ROM, compiled on May 16, 2002.

${ }^{20}$ For instance, the three education variables were set to zero and the "education not reported" regressor assigned a one for individuals not reporting years of schooling.
} 
body weight, physical activity, or multiple health risks; however, females, young adults, minorities, and married persons are underrepresented in the raw data. ${ }^{21}$ Almost one-quarter of the sample smokes, one-ninth consume a pack or more daily, and 2 percent smoke 40 or more cigarettes per day. Most adults (54 percent) are overweight; 18 percent are obese, and 5 percent are severely obese. Twenty-nine percent of respondents engage in no leisure-time physical activity, while 42 percent exercise regularly. ${ }^{22}$ Eleven percent have multiple health risks, as defined above.

Figure 1 shows how unemployment, obesity, and smoking vary over time. The top panel displays annual averages, with 1987 values normalized to 100 . Unemployment increased in the early 1990s and trended downward thereafter. Except for a slight uptick in 1996, adult smoking has declined steadily, falling to 88 percent of its 1987 value at the turn of the century. By contrast, the obesity "epidemic" is clearly demonstrated, with the prevalence of obese adults rising 87 percent (from 13.1 to 24.5 percent) over the 14 year period. ${ }^{23}$

The lower panel of the figure displays patterns with variables detrended (using a linear trend for months elapsed since January 1987) and normalized to have a mean of zero and a standard deviation of one. Previewing the results to follow, unemployment is inversely related to both smoking and obesity. ${ }^{24}$ These correlations may suffer from the aforementioned problems of confounding, since they primarily exploit time-series variation in national data over a single

\footnotetext{
${ }^{21}$ The weights account for unequal probabilities of sample inclusion due to differences in the number of telephones or adults in the household, and in the probability of selection among the geographic strata included in the survey. The weighted data are representative of the adult population in the state. Remington et al., (1988) indicate that weighted estimates from the BRFSS are comparable to those for in person surveys. Further information on the weighting procedure can be obtained from: www.cdc.gov/nccdphp/brfss/ti-weighting.htm.

22 These results are broadly similar to those obtained from other sources. For example, according to U.S. Health and Human Services (2000), 24 percent of adults were smokers (in 1998), 23 percent were obese (from 1988-94), and 40 percent engaged in no leisure-time physical activity (in 1997). Chou, Grossman, and Saffer (2002) show that obesity may be understated in the BRFSS, particularly for women, even after adjusting for self-report bias. ${ }^{23}$ The proportion overweight increased 32 percent (from 46.6 to 61.4 percent); severe obesity grew 136 percent (from 3.4 to 7.9 percent).
} 
business cycle. Nevertheless, they provide a first indication of the movement towards healthier lifestyles in hard economic times, that will be confirmed in the empirical analysis below.

\subsection{Methods}

The basic econometric specification is:

$$
\mathrm{Y}_{\mathrm{ijmt}}=\alpha_{\mathrm{j}}+\mathrm{X}_{\mathrm{ijmt}} \beta+\mathrm{E}_{\mathrm{mj} \mathrm{t}} \gamma+\delta_{\mathrm{m}}+\lambda_{\mathrm{t}}+\varepsilon_{\mathrm{ijm} t}
$$

where $\mathrm{Y}$ is the outcome for individual $\mathrm{i}$ living in state $\mathrm{j}$ interviewed in month $\mathrm{m}$ of year $\mathrm{t}, \mathrm{X}$ is a vector of individual characteristics, E measures economic conditions, $\varepsilon$ is a regression disturbance, and $\alpha, \delta$, and $\lambda$ represent unobserved determinants of lifestyle behaviors associated with the state, calendar month, and survey year.

The month dummy variables control for seasonal variations, such as a decline in physical activity when the weather gets cold. The state fixed-effect holds constant determinants that differ across locations but are time-invariant, like disparities in smoking between Nevada and Utah. The year effect accounts for factors that vary uniformly over time across states (e.g. changes in the calorie-content of meals in fast-food restaurants). The impact of the macroeconomic fluctuations is therefore identified by within-state variations, relative to the changes occurring in other states. ${ }^{25}$ A requirement for the fixed-effect estimates to improve on time-series analysis is that there are substantial independent macroeconomic fluctuations across states over time. This condition is met. For instance, the R-squared for an equation regressing state unemployment rates on the national rate is just $0.33{ }^{26}$

\footnotetext{
${ }^{24}$ The correlation between (detrended) unemployment and smoking (obesity) is -.784 (-.386) with a standard error of $.179(.266)$.

${ }^{25}$ Discussions of "cyclical" variations or "macroeconomic" effects therefore refer to fluctuations within states rather than at the national level and terms like "expansion", "downturn", or "recession" indicate changes in the state economic conditions, rather than technical definitions based on GDP fluctuations or the official timing of recessions.
} 


\section{Lifestyles Get Healthier in Bad Times}

Evidence from a variety of econometric specifications demonstrates that lifestyles

become healthier when economic conditions worsen. Table 2 provides initial results showing the estimated effect of a one percentage point increase in the state unemployment rate on smoking, obesity, physical inactivity, and multiple health risks. ${ }^{27}$ These predictions are obtained from binary probit models, with the Huber-White sandwich estimator used to calculate robust standard errors assuming that observations are independent across states and calendar months but not within states in a given month. ${ }^{28}$ All specifications also control for individual characteristics, month and year dummy variables, and state fixed-effects. The parameter estimates for these regressors are consistent with those obtained in previous research; Appendix Table A.1 provides selected results. ${ }^{29}$

The first column of the table displays (weighted) mean values of the dependent variables. The second shows the predicted effect of a rise in unemployment, with the explanatory variables evaluated at the sample averages. The last two columns supply corresponding estimates of percentage changes in the outcome. The third column does so by dividing the marginal effect

\footnotetext{
${ }^{26}$ See Ruhm (2000) for a more detailed discussion of this issue and additional supporting evidence.

${ }^{27} \mathrm{~A}$ one point rise in unemployment corresponds to an 18 percent ( 0.61 standard deviation) increase from the sample mean of 5.61 percent.

${ }^{28}$ This is done because unemployment rates take the same values for respondents interviewed in a state during a given month and year. Bertrand et al. (2002) raise concern that the presence of serial correlation sometimes leads to severe understatement of the standard errors in difference-in-difference estimates. This problem is much less severe in this application than in their simulations because extensive regression controls are included and the key explanatory variables exhibit considerable variation over time - in contrast to their analysis of legislation dummy variables take the value of zero (one) for all years before (after) enactment. Nevertheless, I also calculated robust standard errors clustering only on states (rather than states and months), which is one of their techniques for dealing with this concern. Doing so increases the standard errors by 8 to 26 percent for the smoking outcomes, 33 to 50 percent for body weight, 165 to 186 percent for physical activity, and 91 percent for multiple health risks. I also estimated unclustered standard errors. There were 0 to 38 percent smaller than those displayed in Table 2.

${ }^{29}$ Obesity and sedentary lifestyles are relatively common among minorities and females, whites and males are more frequent smokers, and less educated persons suffer from all three health risks. Married individuals rarely smoke or are obese, despite relatively low rates of physical activity.
} 
from the second column by the dependent variable mean. ${ }^{30}$ The fourth calculates the change for each respondent (using individual regressor values) and then averages across sample members before dividing by the sample mean. The percentage changes are predicted to be virtually identical using either method and so subsequent tables display results of only the first procedure.

Risky behaviors become less common when the economy deteriorates. A one point growth in unemployment reduces the estimated prevalence of smoking, obesity, and physical inactivity by $.14, .05$, and .45 percentage points $(0.6,0.3$, and 1.8 percent $)$. The decline in tobacco use is concentrated among moderate to heavy smokers, which is interesting given evidence by Ruhm and Black (2002) that cyclical variations in alcohol use are similarly dominated by changes in heavy drinking. Results not displayed indicate that there is a slight decline in average body weight. It is noteworthy that this results entirely from a statistically significant .08 percentage point (1.4 percent) decrease in the predicted prevalence of severe obesity. Indeed, this is larger than the imprecisely estimated reduction in overall obesity (which includes the severely obese), while there is a small and insignificant rise in the fraction predicted to be overweight. The growth in exercise similarly occurs due to a 0.5 percentage point (1.4 percent) reduction in complete inactivity, with no additional drop in the prevalence of irregular exercise. Finally, the 0.2 point (1.8 percent) decline estimated for multiple health risks is larger in relative terms than that for any single unhealthy behavior.

Table 3 demonstrates that the results are robust to changes in samples and specifications. Column (a) repeats findings of the basic model. Specification (b) more fully utilizes the limited available demographic information in the BRFSS by adding interactions between age and sex (1 variable), age and race/ethnicity (3 variables), sex and race/ethnicity (3 variables), sex and marital status (3 variables), and sex and education (3 variables). Doing so has essentially no

\footnotetext{
${ }^{30}$ For instance, a 0.14 percentage point reduction in current smoking represents a 0.6 percent decrease from the base
} 
effect on the unemployment coefficients. Column (c) allows the calendar month effects to differ across the four census regions (Northeast, Midwest, South, and West) which might be important, for example, if physical activity declines more in the winter months in the northeast or midwest than in the south. The results are close to those in the basic model, but with somewhat stronger evidence of reductions in physical inactivity or severe obesity during bad times. Column (d) incorporates sampling weights. The predicted effects are quite similar to those above and always suggest a procyclical variation in smoking, obesity, physical inactivity, and multiple health risks. However, as might be expected, the standard errors increase. ${ }^{31}$

Specification (e) includes state-specific linear time trends, in an attempt to account for unobserved factors that vary within-states over time (such as social norms related to smoking and exercise). Doing so modestly reduces the predicted macroeconomic effects on physical activity, heavy smoking, and multiple health risks. This is no surprise since trends absorb slightly more than a quarter of the variation in unemployment remaining after controlling for state, month, and year effects. It is noteworthy that the estimate for severe obesity is unaffected, even though that on overall obesity (overweight) declines substantially (becomes significantly positive). Chou, Grossman, and Saffer (2002), in their lengthy discussion of this issue, emphasize that the strong secular increase in body weight makes identification difficult in models that contain time trends and recommend against controlling for them. ${ }^{32}$ Thus, the sensitivity of some outcomes is not surprising and, following their reasoning, I exclude trends hereafter.

As an alternative, column (f) limits analysis to the 1987-1994 period. Decreasing the number of years is likely to reduce the influence of within-state changes in omitted factors that

of 23.36 percent.

${ }^{31}$ Wooldridge (1999) and Butler (2000) demonstrate that weighting the data reduces efficiency if sampling is based on exogenous variables and the conditional distribution is correctly specified. Absent evidence that these conditions are violated, I emphasize the results of unweighted regressions.

32 They go even further in preferring estimates that exclude both time trends and general year effects. 
are correlated with unemployment rates, since the size of the trend component declines relative to fluctuations around it; 1987-1994 is useful in this regard since there is no trend in national unemployment rates during this period. The standard errors increase somewhat for the restricted sample, due to the smaller number of observations, but the procyclical variations in smoking, obesity, physical inactivity, and multiple health risks are if anything even stronger than before.

The effects of national business cycles could differ from those of state level fluctuations examined above. One reason is that there are relatively large migration flows in response to changes in local economic conditions (Blanchard and Katz, 1992). This mobility is likely to mitigate against finding healthier lifestyles when the economy weakens, since migrants tend to be young and healthy and usually relocate into areas with robust economies. However, other mechanisms could operate in the reverse direction. For instance, recently arrived residents may be unfamiliar with recreational opportunities or be investing large amounts of time settling into their new locations, raising the cost of undertaking healthy behaviors.

Specification (g) addresses this issue by limiting analysis to the ten states with the slowest rate of population growth (during the 1990s). Since movement into these areas presumably occurs relatively rarely, relatively small cyclical fluctuations would be expected for them, if the negative effects of economic upturns result from in-migration. Evidence that procyclical variations in obesity, physical inactivity, moderate or heavy tobacco use (although not light smoking), and multiple health risks are substantially stronger for these states than for the full sample therefore provides little support for this possibility.

\section{Population Subgroups}

Table 4 provides results for subsamples stratified by employment status, education, sex, and race/ethnicity. For each group, the first column shows the (weighted) mean of the dependent 
variable, the second displays marginal effects (with explanatory variables evaluated at the sample averages), and the third indicates the percentage changes.

Despite significant differences in lifestyles, a procyclical variation in unhealthy behaviors is observed for all groups. The relatively large fluctuations for working individuals are noteworthy and make it unlikely that the macroeconomic effects are restricted to or concentrated among those losing jobs in bad times. A one point rise in unemployment is estimated to reduce smoking, severe obesity, physical inactivity, and multiple health risks by $1.1,2.2,1.5$, and 2.4 percent for employed persons versus $0.6,1.4,1.5$, and 1.8 percent for the full sample. ${ }^{33}$

The coefficients also suggest bigger (although imprecisely estimated) variations in body weight and physical inactivity for males and minorities than for females and non-Hispanic whites: the one point increase in joblessness is predicted to decrease severe obesity among males, blacks, and Hispanics by 2.0, 3.1, and 4.3 percent, compared to 1.0 percent for both females and whites. ${ }^{34}$ These results are salient given the high rates of obesity (and associated conditions such as type-2 diabetes) for non-whites and of early male deaths from cardiovascular disease.

If lifestyles become healthier in bad times because of reductions in job-related stress or increases in non-market leisure time, it makes sense that the changes will be concentrated among groups with high labor force attachments (such as males) or large cyclical fluctuations in employment (like minorities). Consistent with this, the weight loss of African-Americans and males is accompanied by relatively large increases in physical activity; however, the same can not be said for Hispanics. The patterns for tobacco use are also often quite different (e.g. larger

\footnotetext{
${ }^{33}$ However, the composition of employment may vary with macroeconomic conditions. For instance, persons with unhealthy lifestyles may have an easier time finding work when the economy is strong.

34 The increase in unemployment is also estimated to lower the overall obesity prevalence of blacks by a statistically insignificant 0.7 percent and of Hispanics by a significant 1.8 percent, compared to no change for whites.
} 
variations for females than males) suggesting that other mechanisms may account for the macroeconomic effects on smoking. ${ }^{35}$

\section{Mechanisms}

Table 5 examines whether changes in incomes or leisure time help to explain the fluctuations in lifestyles. Specification (a) repeats findings of the basic econometric model. Column (b) adds (state-age-sex-education group) average household incomes and weekly work hours as supplementary regressors. We anticipate obtaining positive parameter estimates for income and hours if these factors account for a portion of the macroeconomic effects (since both increase in good times) and that their inclusion will attenuate the coefficient on unemployment. ${ }^{36}$

The data provide little evidence of a role for cyclical variations in household incomes. A rise of $\$ 1000$ per year boosts the estimated prevalence of severe obesity by .01 percentage points (0.2 percent), has no effect on smoking, and lowers physical inactivity by a significant .14 percentage points ( 0.5 percent). By contrast, the hours coefficients are uniformly positive, as expected if healthier living in hard times is due to decreases in time prices or job-related stress. Working one fewer hour per week predicts a slight .011 percentage point (.05 percent) reduction in smoking but larger $.017, .31$, and .044 point $(0.3,1.0$, and 0.4 percent $)$ declines in severe obesity, physical inactivity, and multiple health risks. Stronger effects for body weight and exercise than smoking make sense, since longer hours directly constrain the ability of individuals to undertake time-intensive activities such as physical activity and preparing home cooked meals, while the impact on tobacco use is likely to be less direct (e.g. reflecting changes in job stress or in complementary behaviors such as drinking).

\footnotetext{
${ }^{35}$ The point estimates suggest smaller macroeconomic effects on current smoking for blacks than whites but the pattern is reversed for tobacco use of a pack or more per day.

${ }^{36}$ A one point rise in unemployment is estimated to lower average household incomes by $\$ 323$ per year (in 2000 year dollars) and employment by .36 hours per week in models that control for year, state, and month dummy variables, and individual characteristics.
} 
Controlling for income and hours attenuates the unemployment coefficient by 5, 8, 17, and 5 percent in the smoking, severe obesity, physical inactivity, and multiple health risk equations. $^{37}$ This probably provides a lower-bound on the role of these factors, since the use of group averages introduces considerable noise into the estimates. Nevertheless, as discussed, this is probably preferable to using individual values of these variables, which will be contaminated by endogeneity and omitted variables biases. A promising future research strategy is to employ longitudinal data with the inclusion of controls for person fixed-effects.

Specification (c) adds regressors for physical activity to the smoking and body weight models. There are two rationales for doing so. First, obesity may decline in bad times because individuals have more time to exercise. Second, tobacco use and physical activity are likely to be negatively correlated, although the direction of causation is uncertain. In particular, while smoking may decrease the interest or ability of individuals to engage in physical activity, some research (e.g. Marcus et al., 1999) suggests that exercise plays an important role in decreasing or stopping tobacco consumption. Higher rates of exercise during bad economic times may therefore provide one reason for the decline in smoking. ${ }^{38}$

Compared to the basic specification (model a), adding controls for physical activity, household incomes and work hours leads to a 16 percent decline in the unemployment coefficient for smoking and a 14 percent decrease for severe obesity (see column c). ${ }^{39}$ As expected, sedentary lifestyles are strongly positively associated with both obesity and smoking.

\footnotetext{
37 The unemployment coefficient decreases 6 (15) percent when the dependent variable is smoking at least 20 (40) cigarettes per day, and by 73 percent when obesity is the outcome.

${ }^{38}$ Some indication of the importance of reverse causation (from smoking to exercise) was obtained by estimating IV models with physical inactivity or irregular exercise as outcomes and smoking instrumented by sum of real state and federal cigarette taxes during the calendar quarter of the survey (using data from Orzechowski and Walker, 2001, provided to me in machine-readable form by Michael Grossman and Frank Chaloupka). These estimates provide no indication that smoking causes physical inactivity (instead there is a small and statistically insignificant negative relationship) but are consistent with a slight decrease in regular exercise.

${ }^{39}$ The unemployment coefficient declines 19 (32) and 85 percent when the dependent variable is smoking at least 20 (40) cigarettes per day and overall obesity.
} 
Moreover, holding physical inactivity constant eliminates the negative hours coefficient observed in specification (b) for smoking and sharply attenuates that for severe obesity. These results suggest that employment hours are positively correlated with smoking and body weight at least partly because individuals have less time or inclination to exercise when work hours increase.

\section{Discussion}

This analysis shows that lifestyle changes provide one mechanism for the improvement in physical health that occurs during temporary downturns. A one percentage point rise in unemployment reduces the estimated prevalence of smoking, severe obesity, physical inactivity, and multiple health risks by $0.6,1.4,1.5$, and 1.8 percent. The decline in body weight is concentrated among severely obese individuals and groups with relatively high risk of early death (like males, African-Americans, and Hispanics). Similarly, increases in exercise largely reflects movements away from complete inactivity and changes in tobacco use disproportionately involve reductions by heavy smokers.

Declining time prices may provide one reason for the healthier behaviors. Consistent with this, cyclical decreases in work hours are associated with reductions in smoking, severe obesity, physical inactivity, and multiple health risks. Conversely, there is little indication that the less risky lifestyles are due to the accompanying fall in incomes.

These results raise interesting questions. For instance, while it makes sense that exercise increases when economic conditions deteriorate because of a rise in non-market time, this direct effect might be reinforced if people are working less hard while on the job and so are not as physically or mentally exhausted when away from it. If so, the parameter estimates for employment hours might combine the effects of variations in effort at both the intensive and 
extensive margins. There could also be other indirect effects, such as changes in sleep, that accompany fluctuations in work hours and affect health. ${ }^{40}$

The findings for multiple health risks also suggest the possibility of poorly understood interactions between lifestyle behaviors. One example, considered above, is the link between physical inactivity and smoking (although the direction of causation is uncertain). A second, which has not been investigated, is that changes in tobacco use may accompany and possibly be caused by fluctuations in drinking. ${ }^{41}$ These continuing uncertainties represent exciting directions for future research.

\footnotetext{
${ }^{40}$ For example, Liu et al. (2002) provide evidence that hours of sleep (work) are negatively (positively) correlated with the risk of nonfatal heart attacks

${ }^{41}$ Dawson (2000), for instance, documents a tight link between alcohol and tobacco use and shows that current drinkers (particularly heavy consumers) are relatively unlikely to have stopped smoking during the prior year.
} 


\section{References}

Allison, David B., Kevin R. Fontaine, JoAnn E. Manson, June Stevens, and Theodore B. VanItallie. 1999. "Annual Deaths Attributable to Obesity in the United States", Journal of the American Medical Association, 282(16), October 27, 1530-1538.

Baker, Dean B. 1985. “The Study of Stress at Work” Annual Review of Public Health, 6, 367-81.

Bertrand, Marianne, Esther Duflo, and Sendhil Mullainathan. 2002. "How Much Should We Trust Difference-In-Difference Estimates”, NBER Working Paper No. 8841, March.

Blanchard, Olivier J. and Lawrence F. Katz. 1992. "Regional Evolutions", Brookings Papers on Economic Activity, No. 1, 1-75.

Brenner, M. Harvey. 1973. Mental Illness and the Economy. Cambridge: Harvard University Press.

Brenner, M. Harvey. 1975. "Trends in Alcohol Consumption and Associated Illnesses: Some Effects of Economic Changes" The American Journal of Public Health, 65(12), 1279-92. $(1975 b)$

Brenner, M. Harvey. 1979. "Mortality and the National Economy" The Lancet, September 15, 568-73.

Brenner, M. Harvey and Anne Mooney. 1983. "Unemployment and Health in the Context of Economic Change” Social Science Medicine, 17(16), 1125-38.

Butler, J.S. 2000. "Efficiency Results of MLE and GMM Estimation With Sampling Weights", Journal of Econometrics 96, 25-37.

Catalano, Ralph and David Dooley. 1983. "Health Effects of Economic Instability: A Test of the Economic Stress Hypothesis" Journal of Health and Social Behavior, 24 (March), 46-60.

Cawley, John. 2000. “Body Weight and Women's Labor Market Outcomes”, National Bureau of Economic Research Working Paper No. 7841, August.

Chaloupka, Frank J. and Kenneth E. Warner. 2000. “The Economics of Smoking” in Anthony J. Culyer and Joseph P. Newhouse (eds.), Handbook of Health Economics, Vol. 1 B. Amsterdam: Elsevier, 1539-1627.

Chay, Kenneth Y. and Michael Greenstone. 2001. "The Impact of Air Pollution on Infant Mortality: Evidence from Geographic Variation in Pollution Shocks Induced By a Recession" mimeo, University of California at Berkeley, July.

Chou, Shin-Yi, Michael Grossman, and Henry Saffer. 2002. “An Economic Analysis of Adult Obesity: Results from the Behavioral Risk Factor Surveillance System”, National Bureau of Economic Research Working Paper No. 9247, October. 
Cook, Philip J. and Gary A. Zarkin. 1986. "Homicide and Economic Conditions: A Replication and Critique of M. Harvey Brenner's New Report to Congress" Journal of Quantitative Criminology, 2(1), 69-80.

Dawson, Deborah A. 2000. “Drinking as a Risk Factor for Sustained Smoking”, Drug and Alcohol Dependence, 59(3), 235-249.

Ettner, Susan L. 1996. "New Evidence on the Relationship Between Income and Health" Journal of Health Economics, 15(1), 67-85.

Evans, William and John D. Graham. 1988. "Traffic Safety and the Business Cycle" Alcohol, Drugs, and Driving, 4(1), 31-38.

Fenwick, Rudy and Mark Tausig. 1994. "The Macroeconomic Context of Job Stress" Journal of Health and Social Behavior, 35(3), 266-82.

Forbes, John F. and Alan McGregor. 1984. "Unemployment and Mortality in Post-War Scotland" Journal of Health Economics, 3, 219-57.

Freeman, Donald G. 1999. "A Note on 'Economic Conditions and Alcohol Problems"” Journal of Health Economics, 18(5), 661-670.

Gerdtham, Ulf G. and Christopher J. Ruhm. 2002. "Deaths Rise in Good Economic Times: Evidence from the OECD", National Bureau of Economic Research Working Paper No. 9357, November.

Goldney, Robert D. 1997. "Unemployment and Health: A Re-appraisal” International Archives of Occupational and Environmental Health, 70(3), 145-147.

Graham, John D., Bei-Hung Chang, and John S. Evans. 1992. "Poorer is Riskier," Risk Analysis, $12,333-337$.

Gravelle, H.S.E., G. Hutchinson, and J. Stern. 1981. "Mortality and Unemployment: A Critique of Brenner's Time Series Analysis” The Lancet, September 26, 675-9.

Harber, Philip, Michael Mullin, Brenda Merz, and Mahshid Tarazi. 2001. "Frequency of Occupational Health Concerns in General Clinics", Journal of Occupational and Environmental Medicine, 43(11), November, 939-945.

Joyce, Theodore and Naci Mocan. 1993. "Unemployment and Infant Health: Time-Series Evidence from the State of Tennessee" Journal of Human Resources, 28(1), 185-203.

Karasek, Robert A. and Töres Theorell. 1990. Healthy Work: Stress, Productivity, and the Reconstruction of Working Life. New York: Basic Books.

Liu, Y., H. Tanaka, and the Fukuoka Heart Study Group. 2002. Occupational and Environmental Medicine, 59(7), July, 447-451. 
Marcus, Bess H., Anna E. Albrecht, Teresa K. King, Alfred F. Parisi, Bernardine M. Pinto, Mary Roberts, Raymond S. Niaura, and David B. Abrams. 1999. "The Efficacy of Exercise as an Aid for Smoking Cessation in Women", Archives of Internal Medicine, 159(11), June 14, 110 .

McAvinchey, Ian D. 1988. "A Comparison of Unemployment, Income, and Mortality Interaction for five European Countries," Applied Economics, 20(4), April, 453-71.

Mokdad, Ali H., Mark K. Serdula, William H. Dietz, Barbara A. Bowman, James S. Marks, Jeffrey Koplan. 1999. "The Spread of the Obesity Epidemic in the United States, 19911998”, Journal of the American Medical Association, 282(16), October 27, 1519-1522.

Mwabu, Germano M. 1988. "Seasonality, The Shadow Price of Time and Effectiveness of Tropical Disease Control Programs" in Herrin, Alejando N. \& Patricia L. Rosenfield (eds.) Economics, Health, and Tropical Diseases, University of the Philippines Press, 259-270.

National Heart, Lung, and Blood Institute. 1998. Clinical Guidelines on the Identification, Evaluation, and Treatment of Overweight and Obesity in Adults. Bethesda, MD: National Institutes of Health.

Neumayer, Eric. 2002. "Recessions Lower (Some) Mortality Rates: Evidence From Germany", mimeo, London School of Economics and Political Science, November.

Orzechowski, William and Robert Walker. 2001. The Tax Burden on Tobacco: Vol. 35, 2000. Arlington, VA: Orzechowski and Walker.

Pritchett, Lant and Lawrence H. Summers. 1996. "Healthier is Wealthier" The Journal of Human Resources, 31(4), 841-868.

Remington Patrick L., Meredith Y. Smith, David F. Williamson, Robert F. Anda, Eileen M. Gentry, and Gary C. Hogelin. 1988. Design, Characteristics, and Usefulness of State-Based Behavioral Risk Factor Surveillance 1981-1986. Public Health Reports, 103(4), 366-75.

Report of the U.S. Preventive Services Taskforce. 1996. Guide to Clinical Preventive Services, Second Edition. Washington D.C.: U.S. Department of Health and Human Services, Office of Disease Prevention and Health Promotion.

Ruhm, Christopher J. 1995. "Economic Conditions and Alcohol Problems", Journal of Health Economics, 14(5), 583-603.

Ruhm, Christopher J. 2000. “Are Recessions Good for Your Health?” Quarterly Journal of Economics, 115(2), 617-650.

Ruhm, Christopher J. 2002. "Economic Expansions Are Unhealthy”, mimeo, University of North Carolina at Greensboro, October.

Ruhm, Christopher J. and William E. Black. 2002. "Does Drinking Really Decrease in Bad Times?" Journal of Health Economics, 21(4), 659-678. 
Snyder, Stephen E. and William N. Evans. 2002. "The Impact of Income on Mortality: Evidence From the Social Security Notch", National Bureau of Economic Research Working Paper No. 9197, September.

Sokejima, Shigeru and Sadanobu Kagamimori. 1998 "Working Hours as a Risk Factor for Acute Myocardial Infarction in Japan: A Case-Control Study" The British Medical Journal, 317 (September 19), 775-780.

Stern, J. 1983. "The Relationship between Unemployment, Morbidity, and Mortality in Britain", Population Studies, 37, 61-74.

Tapia Granados, José A. 2002. "Death Rates and Business Cycle Fluctuations in Spain at the End of the $20^{\text {th }}$ Century: Further Empirical Evidence of Mortality Increase During Economic Expansions", mimeo, New School University.

U.S. Department of Health and Human Services. 1996. Physical Activity and Health: A Report of the Surgeon General. Atlanta, GA: Centers for Disease Control and Prevention, National Center for Chronic Disease Prevention and Health Promotion.

U.S. Department of Health and Human Services. 2000. Healthy People 2010: Understanding and Improving Health, $2^{\text {nd }}$ Edition. Washington D.C.: U.S. Government Printing Office, November.

U.S. Department of Health and Human Services. 2001. The Surgeon General's Call to Action to Prevent and Decrease Overweight and Obesity, Rockville, MD: U.S. Department of Health and Human Services.

Vistnes, Jessica P. and Vivian Hamilton. 1995. "The Time and Monetary Costs of Outpatient Care for Children" American Economic Review, 85(2), 117-121.

Wagstaff, Adam. 1985. “Time Series Analysis of the Relationship Between Unemployment and Mortality: A Survey of Econometric Critiques and Replications of Brenner's Studies" Social Science Medicine, 21(9), 985-96.

Warner, Kenneth E. 1978. "Possible Increases in the Underreporting of Cigarette Consumption", Journal of the American Statistical Association, 73(362), 314-318.

Wooldridge, Jeffrey. 1999. “Asymptotic Properties of Weighted M-Estimators for Variable Probability Samples, Econometrica, 67(6), 1385-1406. 
Table 1:

Sample Means for Selected Variables

\begin{tabular}{|c|c|c|}
\hline Variable & Unweighted Mean & Weighted Mean \\
\hline \multicolumn{3}{|l|}{ Smoking } \\
\hline Current Smoker & .240 & .234 \\
\hline Smokes $\geq 20$ Cigarettes Per Day & .116 & .114 \\
\hline Smokes $\geq 40$ Cigarettes Per Day & .017 & .017 \\
\hline \multicolumn{3}{|l|}{ Height-Adjusted Weight } \\
\hline Overweight (BMI $\geq 25$ ) & .547 & .541 \\
\hline Obese (BMI $\geq 30)$ & .194 & .184 \\
\hline Severely Obese (BMI $\geq 35)$ & .059 & .054 \\
\hline \multicolumn{3}{|l|}{ Leisure-Time Physical Activity } \\
\hline Irregular Exercise & .276 & .283 \\
\hline Physically Inactive & .298 & .294 \\
\hline Multiple Health Risks & .112 & .108 \\
\hline Age (years) & 46.3 & 44.3 \\
\hline Female & .493 & .520 \\
\hline \multicolumn{3}{|l|}{ Race/Ethnicity } \\
\hline Non-Hispanic Black & .084 & .094 \\
\hline Other Non-Hispanic Nonwhite & .038 & .036 \\
\hline Hispanic Origin & .055 & .092 \\
\hline \multicolumn{3}{|l|}{ Education } \\
\hline High School Dropout & .142 & .151 \\
\hline Some College & .261 & .258 \\
\hline College Graduate & .263 & .259 \\
\hline Education Not Reported & .002 & .002 \\
\hline \multicolumn{3}{|l|}{ Current Marital Status } \\
\hline Married/Cohabiting & .569 & .625 \\
\hline Divorced/Separated & .149 & .109 \\
\hline Widowed & .109 & .073 \\
\hline Marital Status Not Reported & .002 & .002 \\
\hline \multicolumn{3}{|l|}{ State-Level Variables } \\
\hline Survey Month Unemployment Rate (\%) & 5.16 & 5.61 \\
\hline Weekly Work Hours (all jobs) & 23.6 & 23.1 \\
\hline Personal Income (thousands of \$2000) & 26.1 & 26.8 \\
\hline
\end{tabular}

Note: Data are from the 1987-2000 years of the BRFSS. Information on state economic conditions is merged in from other sources. The first column shows unweighted means; the second weights observations using BRFSS final sampling weights. Detailed descriptions of the variables are provided in the text of the paper. 
Table 2: Predicted Effect of A

One Percentage Point Increase in Unemployment on Lifestyle Behaviors

\begin{tabular}{|c|c|c|c|c|}
\hline \multirow{2}{*}{ Outcome } & \multirow{2}{*}{$\begin{array}{c}\text { Sample } \\
\text { Mean }\end{array}$} & \multirow{2}{*}{$\begin{array}{c}\text { Marginal } \\
\text { Effect }\end{array}$} & \multicolumn{2}{|c|}{ Percent Change } \\
\hline & & & (a) & (b) \\
\hline \multicolumn{5}{|l|}{ Tobacco Use } \\
\hline Current Smoker & .2336 & $\begin{array}{l}-.0014 \\
(.0005)\end{array}$ & $-0.6 \%$ & $-0.6 \%$ \\
\hline Smokes $\geq 20$ Cigarettes Daily & .1144 & $\begin{array}{l}-.0012 \\
(.0003)\end{array}$ & $-1.0 \%$ & $-1.1 \%$ \\
\hline Smokes $\geq 40$ Cigarettes Daily & .0174 & $\begin{array}{l}-1.9 \mathrm{E}-4 \\
(8.7 \mathrm{E}-5)\end{array}$ & $-1.1 \%$ & $-1.7 \%$ \\
\hline \multicolumn{5}{|l|}{ Body Weight } \\
\hline Overweight (BMI $\geq 25)$ & .5413 & $\begin{array}{c}4.3 \mathrm{E}-4 \\
(5.6 \mathrm{E}-4)\end{array}$ & $0.1 \%$ & $0.1 \%$ \\
\hline Obese (BMI $\geq$ 30) & .1837 & $\begin{array}{l}-5.1 \mathrm{E}-4 \\
(4.3 \mathrm{E}-4)\end{array}$ & $-0.3 \%$ & $-0.3 \%$ \\
\hline Severely Obese $(\mathrm{BMI} \geq 35)$ & .0535 & $\begin{array}{l}-7.5 \mathrm{E}-4 \\
(2.4 \mathrm{E}-4)\end{array}$ & $-1.4 \%$ & $-1.4 \%$ \\
\hline \multicolumn{5}{|l|}{ Leisure-Time Physical Activity } \\
\hline $\begin{array}{l}\text { Irregular Exercise or } \\
\text { Physically Inactive }\end{array}$ & .5771 & $\begin{array}{l}-.0041 \\
(.0008)\end{array}$ & $-0.7 \%$ & $-0.7 \%$ \\
\hline Physically Inactive & .2994 & $\begin{array}{l}-.0045 \\
(.0009)\end{array}$ & $-1.5 \%$ & $-1.4 \%$ \\
\hline Multiple Health Risks & .1077 & $\begin{array}{l}-.0019 \\
(.0004)\end{array}$ & $-1.8 \%$ & $-1.8 \%$ \\
\hline
\end{tabular}

Note: Table shows predicted effects of a one point increase in the state unemployment rate, obtained from binary probit models using data from the 1987-2000 BRFSS. Robust standard errors, calculated assuming that observations are independent across months and states but not within states in a given month, are reported in parentheses. The dependent variable means incorporate sampling weights. The probit models also include month, year, and state dummy variables and controls for age, sex, race/ethnicity, education, and marital status. Multiple health risks refer to individuals with two or more of the following characteristics: current smokers, severely obese, and physically inactive. Sample sizes are 1,490,249 for the smoking outcomes, $1,440,665$ for body weight, 1,081,829 for physical activity, and 1,039,976 for multiple health risks. Marginal effects are evaluated with regressors set to the sample means. Percentage changes are computed by dividing the predicted effect by the dependent variable mean. In the third column predicted effects are evaluated at the regressor means. In the fourth, these are calculated for each individual and then averaged across all sample members. 
Table 3: Additional Econometric Estimates of the Effect of A One Percentage Point Increase in Unemployment

\begin{tabular}{|c|c|c|c|c|c|c|c|}
\hline Outcome & (a) & (b) & (c) & (d) & (e) & (f) & (g) \\
\hline Current Smoker & $\begin{array}{l}-.0014 \\
(.0005)\end{array}$ & $\begin{array}{l}-.0015 \\
(.0005)\end{array}$ & $\begin{array}{l}-.0015 \\
(.0005)\end{array}$ & $\begin{array}{l}-.0026 \\
(.0008)\end{array}$ & $\begin{array}{l}-.0012 \\
(.0005)\end{array}$ & $\begin{array}{l}-.0031 \\
(.0006)\end{array}$ & $\begin{array}{l}-.0009 \\
(.0010)\end{array}$ \\
\hline Smokes $\geq 20$ Cigarettes Daily & $\begin{array}{c}-.0012 \\
(.0003)\end{array}$ & $\begin{array}{l}-.0012 \\
(.0003)\end{array}$ & $\begin{array}{c}-.0012 \\
(.0003)\end{array}$ & $\begin{array}{l}-.0014 \\
(.0005)\end{array}$ & $\begin{array}{l}-.0006 \\
(.0004)\end{array}$ & $\begin{array}{l}-.0018 \\
(.0004)\end{array}$ & $\begin{array}{l}-.0015 \\
(.0006)\end{array}$ \\
\hline Smokes $\geq 40$ Cigarettes Daily & $\begin{array}{l}-1.9 \mathrm{E}-4 \\
(8.7 \mathrm{E}-5)\end{array}$ & $\begin{array}{l}-1.9 \mathrm{E}-4 \\
(8.7 \mathrm{E}-5)\end{array}$ & $\begin{array}{l}-2.0 \mathrm{E}-4 \\
(8.7 \mathrm{E}-5)\end{array}$ & $\begin{array}{l}-1.8 \mathrm{E}-4 \\
(1.5 \mathrm{E}-4)\end{array}$ & $\begin{array}{l}-3.6 \mathrm{E}-5 \\
(9.8 \mathrm{E}-5)\end{array}$ & $\begin{array}{l}-2.3 \mathrm{E}-4 \\
(1.3 \mathrm{E}-4)\end{array}$ & $\begin{array}{c}-4.4 \mathrm{E}-4 \\
(2.0 \mathrm{E}-4)\end{array}$ \\
\hline Overweight $(\mathrm{BMI} \geq 25)$ & $\begin{array}{c}4.3 \mathrm{E}-4 \\
(5.6 \mathrm{E}-4)\end{array}$ & $\begin{array}{c}4.3 \mathrm{E}-4 \\
(5.6 \mathrm{E}-4)\end{array}$ & $\begin{array}{c}4.3 \mathrm{E}-4 \\
(9.1 \mathrm{E}-4)\end{array}$ & $\begin{array}{c}4.3 \mathrm{E}-4 \\
(5.6 \mathrm{E}-4)\end{array}$ & $\begin{array}{l}.0015 \\
(.0006)\end{array}$ & $\begin{array}{c}.0013 \\
(.0008)\end{array}$ & $\begin{array}{l}2.2 \mathrm{E}-4 \\
(.0012)\end{array}$ \\
\hline Obese (BMI $\geq 30$ ) & $\begin{array}{c}-5.1 \mathrm{E}-4 \\
(4.3 \mathrm{E}-4)\end{array}$ & $\begin{array}{l}-5.1 \mathrm{E}-4 \\
(4.3 \mathrm{E}-4)\end{array}$ & $\begin{array}{c}-5.2 \mathrm{E}-4 \\
(7.5 \mathrm{E}-4)\end{array}$ & $\begin{array}{l}-5.8 \mathrm{E}-4 \\
(4.3 \mathrm{E}-4)\end{array}$ & $\begin{array}{c}-1.5 \mathrm{E}-4 \\
(4.9 \mathrm{E}-4)\end{array}$ & $\begin{array}{l}-.0013 \\
(.0005)\end{array}$ & $\begin{array}{c}-6.3 \mathrm{E}-4 \\
(8.9 \mathrm{E}-4)\end{array}$ \\
\hline Severely Obese $(\mathrm{BMI} \geq 35)$ & $\begin{array}{l}-7.5 \mathrm{E}-4 \\
(2.4 \mathrm{E}-4)\end{array}$ & $\begin{array}{c}-7.6 \mathrm{E}-4 \\
(2.4 \mathrm{E}-4)\end{array}$ & $\begin{array}{l}-8.6 \mathrm{E}-4 \\
(2.4 \mathrm{E}-4)\end{array}$ & $\begin{array}{l}-7.6 \mathrm{E}-4 \\
(4.2 \mathrm{E}-4)\end{array}$ & $\begin{array}{l}-7.8 \mathrm{E}-4 \\
(2.8 \mathrm{E}-4)\end{array}$ & $\begin{array}{l}-9.8 \mathrm{E}-4 \\
(2.7 \mathrm{E}-4)\end{array}$ & $\begin{array}{l}-.0013 \\
(.0006)\end{array}$ \\
\hline Physically Inactive & $\begin{array}{c}-.0045 \\
(.0009)\end{array}$ & $\begin{array}{l}-.0044 \\
(.0009)\end{array}$ & $\begin{array}{l}-.0051 \\
(.0009)\end{array}$ & $\begin{array}{l}-.0036 \\
(.0012)\end{array}$ & $\begin{array}{l}-.0027 \\
(.0009)\end{array}$ & $\begin{array}{l}-.0048 \\
(.0010)\end{array}$ & $\begin{array}{l}-.0151 \\
(.0018)\end{array}$ \\
\hline Multiple Health Risks & $\begin{array}{c}-.0019 \\
(.0004)\end{array}$ & $\begin{array}{l}-.0019 \\
(.0004)\end{array}$ & $\begin{array}{c}-.0022 \\
(.0004)\end{array}$ & $\begin{array}{l}-.0021 \\
(.0007)\end{array}$ & $\begin{array}{l}-.0013 \\
(.0004)\end{array}$ & $\begin{array}{l}-.0030 \\
(.0005)\end{array}$ & $\begin{array}{c}-.0054 \\
(.0009)\end{array}$ \\
\hline Regression Details & $\begin{array}{l}\text { Basic } \\
\text { Model }\end{array}$ & $\begin{array}{l}\text { Covariate } \\
\text { Interactions }\end{array}$ & $\begin{array}{l}\text { Region- } \\
\text { Month } \\
\text { Effects }\end{array}$ & $\begin{array}{l}\text { Weighted } \\
\text { Estimates }\end{array}$ & $\begin{array}{l}\text { State Time } \\
\text { Trends }\end{array}$ & $\begin{array}{c}\text { 1987-1994 } \\
\text { Period }\end{array}$ & $\begin{array}{c}\text { Slow } \\
\text { Growing } \\
\text { States }\end{array}$ \\
\hline
\end{tabular}


Note: See note on Table 2. Specification (b) includes 13 supplementary regressors interacting age and sex, age and race/ethnicity, sex and race/ethnicity, sex and marital status, and sex and education. Column (c) includes interactions between the four census regions (Northeast, Midwest, South, and West) and calendar month dummy variables. Model (d) incorporate sampling weights. Specification (e) includes statespecific linear time trends (months elapsed since January 1987). Column (f) limits the sample to the 1987-1994 period, and model (g) to the 10 states with the slowest population growth rate between 1990 and 2000 (North Dakota, West Virginia, Pennsylvania, Connecticut, Maine, Rhode Island, Ohio, Iowa, New York, and Massachusetts). Predicted effects are calculated with the independent variable evaluated at the sample means. 
Table 4: Predicted Effects of Macroeconomic Conditions on the Lifestyle Behaviors of Population Subgroups

\begin{tabular}{|c|c|c|c|c|c|c|c|c|c|c|c|c|}
\hline \multirow{2}{*}{ Group } & \multicolumn{3}{|c|}{ Current Smoker } & \multicolumn{3}{|c|}{ Severely Obese } & \multicolumn{3}{|c|}{ Physically Inactive } & \multicolumn{3}{|c|}{ Multiple Health Risks } \\
\hline & $\mu$ & $\beta$ & $\% \Delta$ & $\mu$ & $\beta$ & $\% \Delta$ & $\mu$ & $\beta$ & $\% \Delta$ & $\mu$ & $\beta$ & $\% \Delta$ \\
\hline Full Sample & .2336 & $\begin{array}{l}-.0014 \\
(.0005)\end{array}$ & $-0.6 \%$ & .0535 & $\begin{array}{l}-7.5 \mathrm{E}-4 \\
(2.4 \mathrm{E}-4)\end{array}$ & $-1.4 \%$ & .2994 & $\begin{array}{l}-.0045 \\
(.0009)\end{array}$ & $-1.5 \%$ & .1077 & $\begin{array}{l}-.0019 \\
(.0004)\end{array}$ & $-1.8 \%$ \\
\hline Employed & .2529 & $\begin{array}{l}-.0025 \\
(.0006)\end{array}$ & $-1.1 \%$ & .0503 & $\begin{array}{l}-.0011 \\
(.0003)\end{array}$ & $-2.2 \%$ & .2670 & $\begin{array}{l}-.0040 \\
(.0009)\end{array}$ & $-1.5 \%$ & .1066 & $\begin{array}{l}-.0025 \\
(.0005)\end{array}$ & $-2.4 \%$ \\
\hline No College & .2872 & $\begin{array}{l}-.0017 \\
(.0007)\end{array}$ & $-0.6 \%$ & .0644 & $\begin{array}{l}-6.9 \mathrm{E}-4 \\
(3.8 \mathrm{E}-4)\end{array}$ & $-1.1 \%$ & .3876 & $\begin{array}{l}-.0064 \\
(.0012)\end{array}$ & $-1.7 \%$ & .1533 & $\begin{array}{l}-.0029 \\
(.0007)\end{array}$ & $-1.9 \%$ \\
\hline Some College & .1842 & $\begin{array}{l}-.0011 \\
(.0006)\end{array}$ & $-0.6 \%$ & .0435 & $\begin{array}{l}-7.4 \mathrm{E}-4 \\
(3.1 \mathrm{E}-4)\end{array}$ & $-1.7 \%$ & .2057 & $\begin{array}{l}-.0027 \\
(.0008)\end{array}$ & $-1.3 \%$ & .0695 & $\begin{array}{l}-.0012 \\
(.0004)\end{array}$ & $-1.7 \%$ \\
\hline Males & .2537 & $\begin{array}{l}-8.3 \mathrm{E}-4 \\
(7.3 \mathrm{E}-4)\end{array}$ & $-0.3 \%$ & .0442 & $\begin{array}{l}-9.0 \mathrm{E}-4 \\
(3.4 \mathrm{E}-4)\end{array}$ & $-2.0 \%$ & .2726 & $\begin{array}{l}-.0053 \\
(.0011)\end{array}$ & $-2.3 \%$ & .1066 & $\begin{array}{l}-.0026 \\
(.0005)\end{array}$ & $-2.4 \%$ \\
\hline Females & .2151 & $\begin{array}{l}-.0018 \\
(.0006)\end{array}$ & $-0.8 \%$ & .0624 & $\begin{array}{l}-6.5 \mathrm{E}-4 \\
(3.4 \mathrm{E}-4)\end{array}$ & $-1.0 \%$ & .3145 & $\begin{array}{l}-.0039 \\
(.0010)\end{array}$ & $-1.3 \%$ & .1087 & $\begin{array}{l}-.0014 \\
(.0005)\end{array}$ & $-1.3 \%$ \\
\hline $\begin{array}{l}\text { Non-Hispanic } \\
\text { Whites }\end{array}$ & .2393 & $\begin{array}{l}-.0016 \\
(.0005)\end{array}$ & $-0.7 \%$ & .0489 & $\begin{array}{l}-4.9 \mathrm{E}-4 \\
(2.7 \mathrm{E}-4)\end{array}$ & $-1.0 \%$ & .2749 & $\begin{array}{l}-.0042 \\
(.0009)\end{array}$ & $-1.5 \%$ & .1046 & $\begin{array}{l}-.0019 \\
(.0004)\end{array}$ & $-1.8 \%$ \\
\hline $\begin{array}{l}\text { Non-Hispanic } \\
\text { Blacks }\end{array}$ & .2341 & $\begin{array}{l}-.0007 \\
(.0016)\end{array}$ & $-0.3 \%$ & .0941 & $\begin{array}{l}-.0030 \\
(.0012)\end{array}$ & $-3.1 \%$ & .3759 & $\begin{array}{l}-.0071 \\
(.0029)\end{array}$ & $-1.9 \%$ & .1433 & $\begin{array}{l}-.0026 \\
(.0016)\end{array}$ & $-1.8 \%$ \\
\hline Hispanics & .1953 & $\begin{array}{l}-.0017 \\
(.0019)\end{array}$ & $-0.9 \%$ & .0591 & $\begin{array}{l}-.0026 \\
(.0011)\end{array}$ & $-4.3 \%$ & .3750 & $\begin{array}{l}-.0018 \\
(.0026)\end{array}$ & $-0.5 \%$ & .1065 & $\begin{array}{c}-.0017 \\
(.0016)\end{array}$ & $-1.6 \%$ \\
\hline
\end{tabular}


Note: See note on Table 2. The regression equations correspond to specification (a) of that table. For each outcome, the first column shows (weighted) means of the dependent variable, the second displays predicted effects of a one percentage point increase in the state unemployment rate, evaluated with the regressors set to the sample means and robust standard errors shown in parentheses. The third column indicates the percentage change, calculated by dividing the marginal effect by the dependent variable mean. Sample sizes for employed individuals range between 651,003 and 927,905; for those without college from 491,744 to 702,559; for the college educated from 546,623 to 784,552; for males from 442,467 to 618,633 ; for females from 597,509 to 871,616 ; for whites from 856,317 to $1,226,121$; for blacks from 87,386 to 124,913 ; and for Hispanics from 56,040 to 82,271 . 
Table 5: Additional Estimates of the Effects of Economic Factors on Lifestyle Behaviors

\begin{tabular}{|c|c|c|c|c|c|c|c|c|c|c|}
\hline \multirow{2}{*}{ Regressor } & \multicolumn{3}{|c|}{ Current Smoker } & \multicolumn{3}{|c|}{ Severely Obese } & \multicolumn{2}{|c|}{ Physically Inactive } & \multicolumn{2}{|c|}{ Multiple Health Risks } \\
\hline & (a) & (b) & (c) & (a) & (b) & (c) & (a) & (b) & (a) & (b) \\
\hline Unemployment Rate & $\begin{array}{l}-.0014 \\
(.0005)\end{array}$ & $\begin{array}{l}-.0014 \\
(.0005)\end{array}$ & $\begin{array}{l}-.0012 \\
(.0005)\end{array}$ & $\begin{array}{l}-7.5 \mathrm{E}-4 \\
(2.4 \mathrm{E}-4)\end{array}$ & $\begin{array}{l}-6.9 \mathrm{E}-4 \\
(2.5 \mathrm{E}-4)\end{array}$ & $\begin{array}{l}-6.5 \mathrm{E}-4 \\
(2.5 \mathrm{E}-4)\end{array}$ & $\begin{array}{l}-.0045 \\
(.0009)\end{array}$ & $\begin{array}{l}-.0037 \\
(.0009)\end{array}$ & $\begin{array}{l}-.0019 \\
(.0004)\end{array}$ & $\begin{array}{l}-.0018 \\
(.0004)\end{array}$ \\
\hline Household Income & & $\begin{array}{l}-1.0 \mathrm{E}-5 \\
(7.9 \mathrm{E}-5)\end{array}$ & $\begin{array}{l}-2.8 \mathrm{E}-5 \\
(7.9 \mathrm{E}-5)\end{array}$ & & $\begin{array}{c}9.6 \mathrm{E}-5 \\
(4.1 \mathrm{E}-5)\end{array}$ & $\begin{array}{c}1.3 \mathrm{E}-4 \\
(4.0 \mathrm{E}-5)\end{array}$ & & $\begin{array}{c}-.0014 \\
(.0001)\end{array}$ & & $\begin{array}{l}-3.5 \mathrm{E}-4 \\
(6.7 \mathrm{E}-5)\end{array}$ \\
\hline Work Hours & & $\begin{array}{c}1.1 \mathrm{E}-4 \\
(7.3 \mathrm{E}-5)\end{array}$ & $\begin{array}{l}-7.4 \mathrm{E}-5 \\
(7.3 \mathrm{E}-5)\end{array}$ & & $\begin{array}{c}1.7 \mathrm{E}-4 \\
(3.6 \mathrm{E}-5)\end{array}$ & $\begin{array}{c}9.9 \mathrm{E}-5 \\
(3.6 \mathrm{E}-5)\end{array}$ & & $\begin{array}{c}.0031 \\
(.0001)\end{array}$ & & $\begin{array}{c}4.4 \mathrm{E}-4 \\
(6.0 \mathrm{E}-5)\end{array}$ \\
\hline Irregular Exercise & & & $\begin{array}{c}.0470 \\
(.0011)\end{array}$ & & & $\begin{array}{c}.0156 \\
(.0006)\end{array}$ & & & & \\
\hline Physically Inactive & & & $\begin{array}{c}.0902 \\
(.0012)\end{array}$ & & & $\begin{array}{c}.0375 \\
(.0007)\end{array}$ & & & & \\
\hline
\end{tabular}

Note: See note on Table 2. Table shows the predicted effect of a one unit change in the specified variable from probit models that also control for personal characteristics and month, state, and year dummy variables. Household incomes, in models (b) and (c), refer to average annual incomes in the state and survey year (in thousands of 2000 year dollars) for sixteen groups stratified by age, sex, and education. These are estimated with incomes calculated as the midpoints of the ranges of six or seven bounded categories and 150 percent of the unbounded top category. Work hours refer to average weekly hours in all jobs for adults, in the same state-age-sex-education cell as the respondent, during the three months ending with the survey month. Further details on these variables are provided in the text. 
Table A.1: Detailed Regression Results for Selected Outcomes

\begin{tabular}{|c|c|c|c|c|}
\hline Regressor & Smoker & Severely Obese & $\begin{array}{l}\text { Physically } \\
\text { Inactive }\end{array}$ & $\begin{array}{c}\text { Multiple } \\
\text { Health Risks }\end{array}$ \\
\hline State Unemployment Rate & $\begin{array}{l}-.0014 \\
(.0005)\end{array}$ & $\begin{array}{l}-7.5 \mathrm{E}-4 \\
(2.4 \mathrm{E}-4)\end{array}$ & $\begin{array}{l}-.0045 \\
(.0009)\end{array}$ & $\begin{array}{l}-.0019 \\
(.0004)\end{array}$ \\
\hline Age & $\begin{array}{c}.0137 \\
(.0001)\end{array}$ & $\begin{array}{c}.0073 \\
(.0001)\end{array}$ & $\begin{array}{c}.0033 \\
(.0002)\end{array}$ & $\begin{array}{c}.0102 \\
(.0001)\end{array}$ \\
\hline Age Squared & $\begin{array}{c}-.0002 \\
(1.5 \mathrm{E}-6)\end{array}$ & $\begin{array}{c}7.3 \mathrm{E}-5 \\
(7.2 \mathrm{E}-7)\end{array}$ & $\begin{array}{l}-4.3 \mathrm{E}-6 \\
(1.6 \mathrm{E}-6)\end{array}$ & $\begin{array}{l}-1.1 \mathrm{E}-4 \\
(1.2 \mathrm{E}-6)\end{array}$ \\
\hline Female & $\begin{array}{l}-.0371 \\
(.0008)\end{array}$ & $\begin{array}{c}.0164 \\
(.0004)\end{array}$ & $\begin{array}{c}.0157 \\
(.0010)\end{array}$ & $\begin{array}{l}-.0024 \\
(.0006)\end{array}$ \\
\hline Black & $\begin{array}{l}-.0559 \\
(.0012)\end{array}$ & $\begin{array}{c}.0423 \\
(.0009)\end{array}$ & $\begin{array}{c}.0784 \\
(.0019)\end{array}$ & $\begin{array}{c}.0124 \\
(.0012)\end{array}$ \\
\hline Other Nonwhite & $\begin{array}{l}-.0045 \\
(.0022)\end{array}$ & $\begin{array}{c}.0017 \\
(.0011)\end{array}$ & $\begin{array}{c}.0887 \\
(.0030)\end{array}$ & $\begin{array}{c}.0111 \\
(.0019)\end{array}$ \\
\hline Hispanic & $\begin{array}{l}-.0663 \\
(.0016)\end{array}$ & $\begin{array}{c}.0087 \\
(.0009)\end{array}$ & $\begin{array}{c}.0867 \\
(.0028)\end{array}$ & $\begin{array}{l}-.0071 \\
(.0013)\end{array}$ \\
\hline High School Dropout & $\begin{array}{c}.0652 \\
(.0013)\end{array}$ & $\begin{array}{l}.0216 \\
(.0007)\end{array}$ & $\begin{array}{c}.0937 \\
(.0016)\end{array}$ & $\begin{array}{c}.0582 \\
(.0011)\end{array}$ \\
\hline Some College & $\begin{array}{l}-.0537 \\
(.0008)\end{array}$ & $\begin{array}{l}-.0048 \\
(.0004)\end{array}$ & $\begin{array}{l}-.0859 \\
(.0011)\end{array}$ & $\begin{array}{l}-.0404 \\
(.0006)\end{array}$ \\
\hline College Graduate & $\begin{array}{l}-.1548 \\
(.0008)\end{array}$ & $\begin{array}{l}-.0237 \\
(.0004)\end{array}$ & $\begin{array}{l}-.1522 \\
(.0011)\end{array}$ & $\begin{array}{l}-.0885 \\
(.0006)\end{array}$ \\
\hline Married & $\begin{array}{l}-.0472 \\
(.0011)\end{array}$ & $\begin{array}{l}-.0177 \\
(.0006)\end{array}$ & $\begin{array}{c}.0141 \\
(.0015)\end{array}$ & $\begin{array}{l}-.0194 \\
(.0010)\end{array}$ \\
\hline Divorced/Separated & $\begin{array}{c}.0887 \\
(.0015)\end{array}$ & $\begin{array}{l}-.0131 \\
(.0006)\end{array}$ & $\begin{array}{c}.0401 \\
(.0019)\end{array}$ & $\begin{array}{c}.0304 \\
(.0013)\end{array}$ \\
\hline Widowed & $\begin{array}{c}.0350 \\
(.0019)\end{array}$ & $\begin{array}{l}-.0061 \\
(.0008)\end{array}$ & $\begin{array}{c}.0306 \\
(.0022)\end{array}$ & $\begin{array}{c}.0108 \\
(.0015)\end{array}$ \\
\hline
\end{tabular}

Note: See note on table 2. The probit models also include month, year, and state dummy variables, as well as dummy variables indicating missing information on marital status or education. Table shows the predicted effect of a one unit change in the specified variable (from the mean value for continuous variables and from zero to one for dummy variables), with other regressors evaluated at the sample means. 

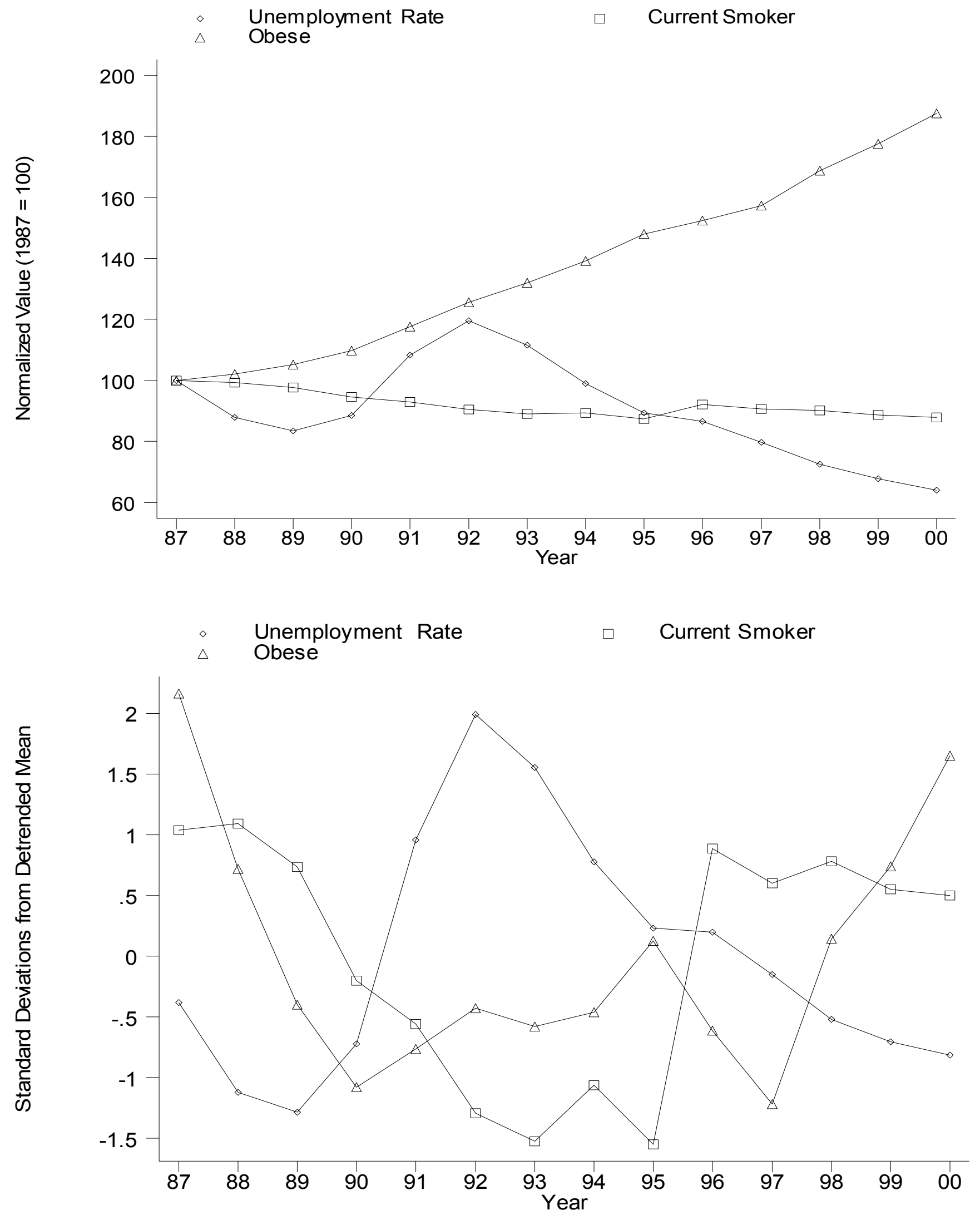

Figure 1: Trends in Unemployment, Smoking, and Obesity 